Article

\title{
Pollination Services from Insects in Homegardens in the Chengdu Plain will be Confronted with Crises
}

\author{
Qin Liu ${ }^{1,2,3, *}$, Pei Xu ${ }^{1,2, *}$, Kun Yan ${ }^{1,2}$ and Yingman Guo ${ }^{1,2}$ \\ 1 Institute of Mountain Hazards and Environment, Chinese Academy of Sciences, Chengdu 610041, China; \\ yankun@imde.ac.cn (K.Y.); Solarying369@163.com (Y.G.) \\ 2 Wanzhou Key Regional Ecology and Environment Monitoring Station of Three Gorges Project Ecological \\ Environmental Monitoring System, Wanzhou 404020, China \\ 3 College of Earth Sciences, Chengdu University of Technology, Chengdu 610059, China \\ * Correspondence: Liuqin@imde.ac.cn (Q.L.); Xupei@imde.ac.cn (P.X.); Tel.: +86-028-8522-0893 (Q.L.)
}

Received: 7 March 2019; Accepted: 8 April 2019; Published: 11 April 2019

check for updates

\begin{abstract}
Chengdu Plain is one of China's most important agricultural production zones and has a large human population. Agricultural crops require insect pollination to increase yield and quality, which is especially important in plains areas where forest area is small. Homegardens are the main habitat of pollinators. The present study identified the importance of insect pollination in homegardens in the Chengdu Plain through field investigations and comparative experiments and revealed the risk to pollination services caused by the decrease in diversity and population of managed and wild pollinators. The results showed that (1) prohibiting all insect pollination (treatment A) and prohibiting managed bee pollination (treatment B) significantly reduced the yield and seed number of rapeseed and significantly reduced the size, weight, and sweetness of peach fruit, but had no significant effects on plums; (2) the dependence on insect pollination and the economic values of insect pollination for rapeseed and peaches are 0.56 and $\$ 85.1$ million and 0.44 and $\$ 31.0$ million, respectively; (3) there were 23 flower-visiting pollinator species at the experimental sites including: four species of managed bees and 19 species of wild pollinators. The peak time for pollinators to visit flowers was 11:00 to 15:00, and the managed bees accounted for over $67.55 \%$ of these visits; (4) within a radius of $1000 \mathrm{~m}$ from the site, $58.06 \%$ of the bees were non-locally managed, and the bee population managed locally by farmers decreased; and (5) compared with 2008, the number of homegardens decreased by $17.24 \%$, the managed bees within the homegardens decreased by $62.05 \%$, and the disappearance and destruction of homegardens led to a significant reduction in wild pollinators.
\end{abstract}

Keywords: homegarden; Linpan; Chengdu plain; pollination; ecosystem services

\section{Introduction}

Insect pollination is a very important ecosystem service [1-4] that provides essential support for food security and ecosystem stability [5]. Approximately $90 \%$ of the world's angiosperms require insect pollination [4], and $85 \%$ of agricultural crops have increased production with insect pollination $[2,6,7]$. The agricultural economic value of pollination services exceeds 153 billion Euros [6,8]. However, under the influence of agricultural intensification, climate change, invasion by foreign species, and pest and disease transmission [9-11], the diversity and abundance of pollinators are decreasing continuously [12,13]. Therefore, organic farming models and ecological measures are being actively developed around the world [14,15]; these include AES (agri-environmental schemes ) plans [16], hedges [17], and flower belts $[18,19]$ to improve landscape heterogeneity and connectivity $[20,21]$, to protect or restore insect habitat and vegetation diversity [22-24], and to maintain pollination services $[25,26]$. 
Insect pollination services have not received sufficient attention in many places [27-29]. The Chengdu Plain is one of the most important agricultural production zones in China [30,31]. It is known as the 'land of abundance' and has a farming-based civilization thousands of years old [32]. The Chengdu Plain is also one of the most populated areas in China [33]. The homegarden-style settlements that consist of rural houses with surrounding forests are called 'Linpan' [34-37], and provide a small-scale habitat in a relatively regular shape (most are nearly circular) with high vegetation coverage [34]. There is a large number of Linpan in the Chengdu Plain, and the density is high [38]. In Chengdu City, which has a residential population of 3,655,600, there are approximately 121,100 Linpan. The Linpan and farmlands of the Chengdu Plain constitute a unique agricultural landscape $[39,40]$. The Linpan not only provide ecological services such as product supply, climate regulation, and biodiversity conservation [41-45], but also pollination service because it is the main natural habitat for managed bees and wild pollinators [28].

In recent years, approximately $27 \%$ of traditional Linpan have been lost-they have been converted into construction land or cultivated land-and another $40 \%$ have been altered [46,47]. Agricultural production methods have scaled up and intensified, at the cost of decreasing pollinator diversity and populations. Therefore, the importance of insect pollination services in the Chengdu Plain should receive more attention, and this study focused on evaluating (a) pollination status and crop pollination dependence; (b) the main risks to insect pollination services; (c) suggestions for synergistic improvement of Linpan protection and farmland pollination services.

\section{Study Area}

The average density of homegardens per square kilometer is approximately 14.64 in the Chengdu Plain [38]. The Chengdu Plain is an alluvial plain of the Minjiang and Tuojiang Rivers, between the Qionglaiand Longquan Mountains. The plain is $200 \mathrm{~km}$ long from south to north and 40 to $70 \mathrm{~km}$ wide, comprising an area of approximately $18,800 \mathrm{~km}^{2}$ (Figure 1).

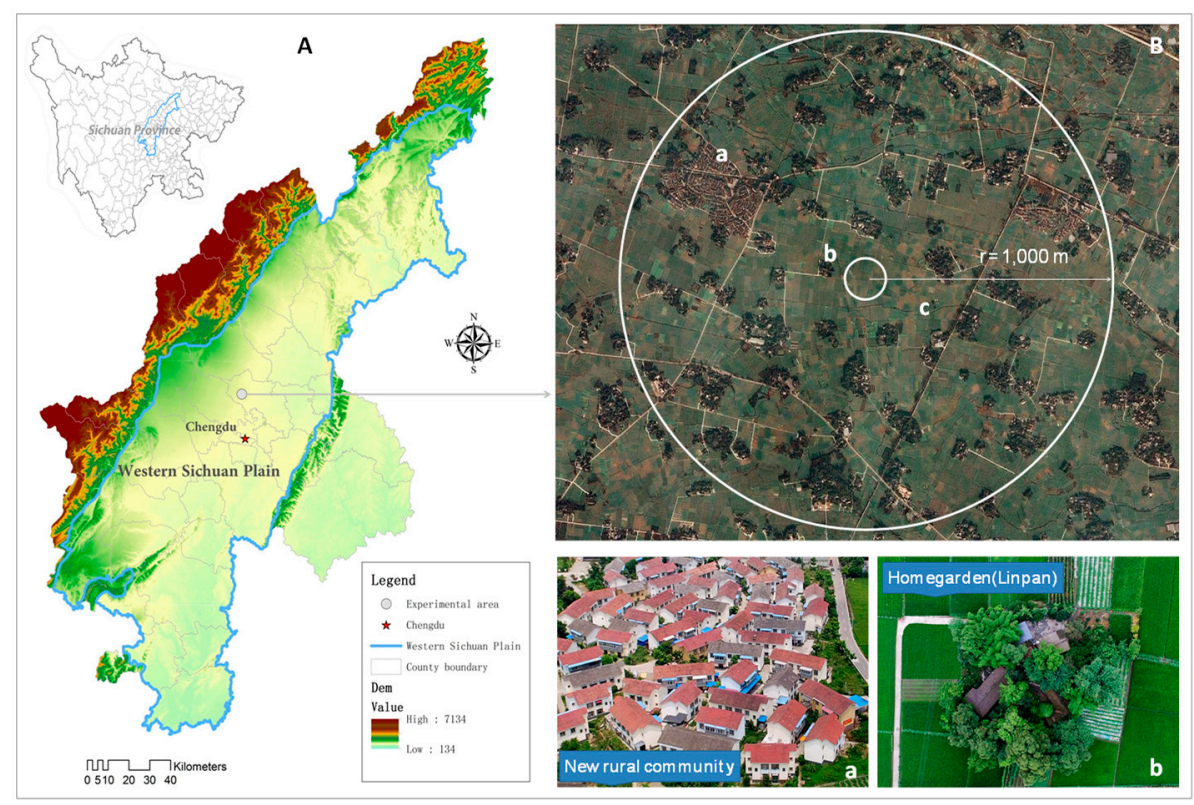

Figure 1. Study areas in the Chengdu Plain. (A) Distribution of western Sichuan Plain and location of the experimental area; (B) experimental area in Xinmin Town, Xindu, Chengdu (circle with $\mathrm{r}=1000 \mathrm{~m}$ ). a, new rural community; b, homegarden (Linpan); c, farmland. 


\section{Methods and Data Analysis}

\subsection{Insect Pollination Experiment}

The experimental area comprised a circle with a radius of $1000 \mathrm{~m}$ in Xinmin Town, $24.90 \mathrm{~km}$ from downtown Chengdu City (Figure 1). The study area has traditional homegardens, lost homegardens, and altered homegardens, and it was selected to carry out investigations and experiments because it is representative of the area [34] (Figure 1). Three typical agricultural crops (rapeseed, peach, and plum) in the Chengdu Plain were used in this study. To evaluate insect pollination, three treatments were applied during the flowering period: (1) Nylon mesh covering, excluding all insect pollination (A); (2) nylon mesh covering, excluding only managed bee pollination (B); and (3) no covering, permitting all insect pollination (CK) [28,48,49] (Figures 2 and 3). The experimental period was in March to July 2017. Test indicators include:

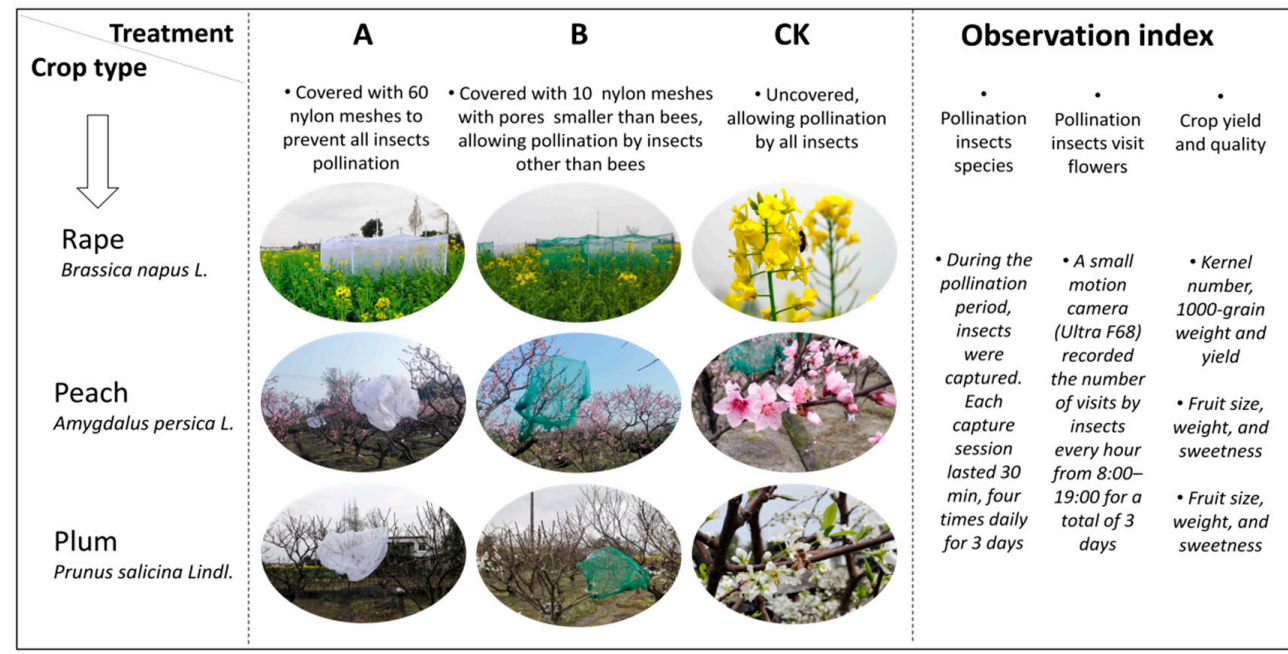

Figure 2. Experimental design and test indicators.
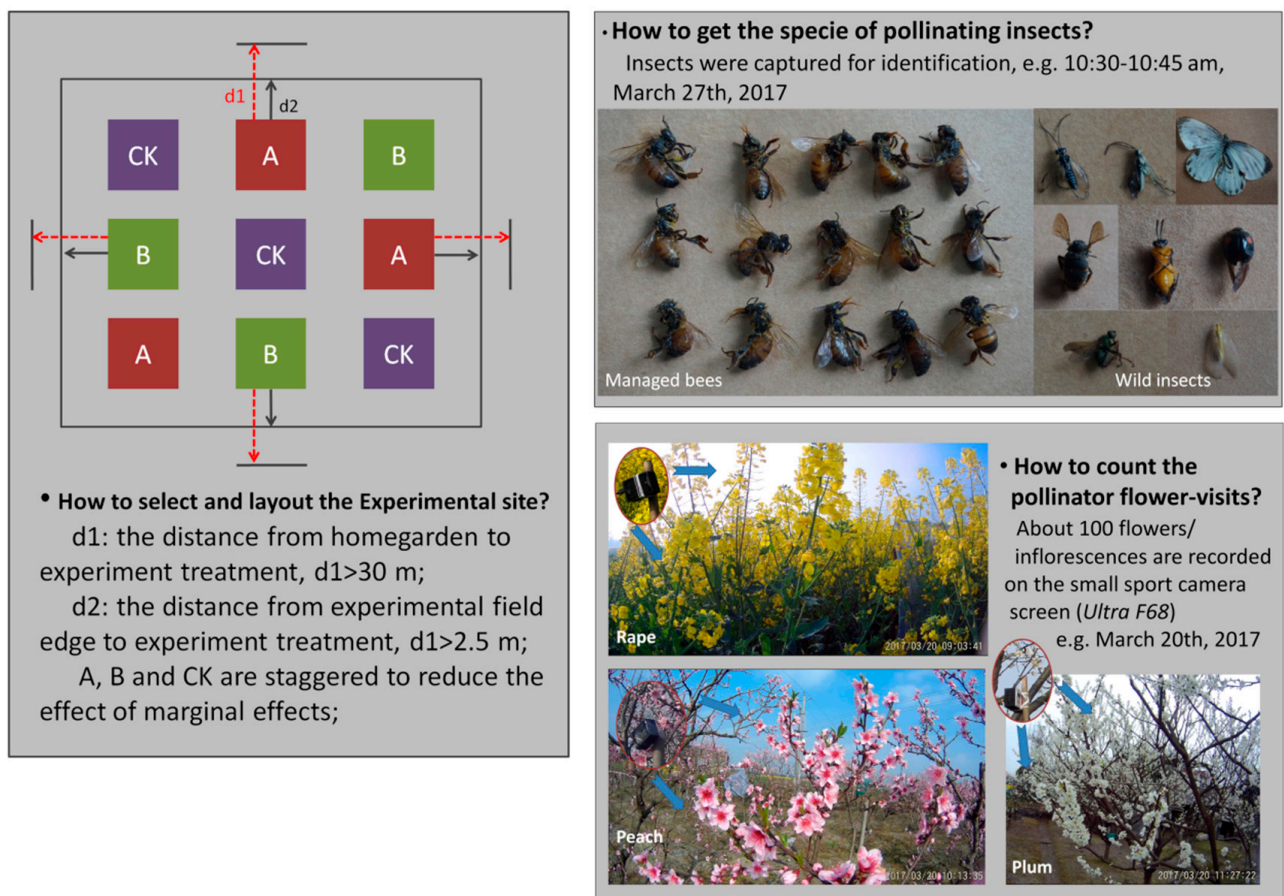

Figure 3. Experimental methods. 
(1) Experimental site selection and layout: A, B, and CK were staggered to reduce the effect of marginal effects, the distance from homegarden to experiment treatment was greater than $30 \mathrm{~m}$, and the distance from experimental field edge to experiment treatment was greater than $2.5 \mathrm{~m}$. The test fields of rapeseed were $3 \mathrm{~m} \times 3 \mathrm{~m}$, the spacing of rapeseed line was $0.40 \mathrm{~m} \times 0.35 \mathrm{~m}$, and the sample of $3 \mathrm{~m} \times 3 \mathrm{~m}$ included 56 rapeseed, which can increase the sample size and reduce the experimental error. Each treatment had three replicates. Peach and plum were examined on separate side branches (approximately 50 to 60 flowers), with six replicates per treatment, to ensure enough samples.

(2) Pollinator species: During the pollination period, insects were captured for identification. Using insect nets to capture different species of insects in the $2 \mathrm{~m} \times 2 \mathrm{~m}$ range, all captured insects were placed in plastic test tubes filled with alcohol, taken back to the laboratory to make specimens, and their species identified. Each capture session lasted $30 \mathrm{~min}$, and these were performed four times daily for 3 days (20, 24, and 27 March 2017). The capture time was 9:00 to 09:30, 11:30 to 12:00, 14:00 to 14:30, and 16:30to 17:00 every day.

(3) Pollinator flower-visits: A small sports camera (Ultra F68) was used to record the number of visits by managed bees and wild insects every hour from 8:00 to 18:00, for a total of 3 days. By adjusting the height and resolution, the camera screen can capture information such as the species of insects visited and the number of visits. In order to maintain consistency and improve statistical accuracy, 100 flowers (peach, plum) and 100 inflorescences (rapeseed) closest to the screen were marked as statistical objects. The video data was then brought back to the lab for playback, statistics, and recording. An insect staying on the flower for $5 \mathrm{~s}$ or more was counted as a flower-visit.

(4) Crop yield and quality: The different treatments of rapeseed were naturally air-dried, shelled, collected, and dried to be weighed. The seed number of 6 types of rapeseed were randomly selected from each sample and were counted, and 6 1000-grain weights were weighed for each sample. When the peach and plum fruits of different treatments were ripe, all were picked, and each fruit was weighed by an electronic balance, the diameter of each fruit was measured by a vernier caliper, the fruit skin was cut with a knife, and 2 to 3 drops of juice were taken in a hand-held sweet to measure the sweetness.

\subsection{Crop Pollination Dependence $\left(D_{i}\right)$}

The economic value of crop pollination in the Chengdu Plain was calculated following the method of Gallai [6]. Firstly, the economic value of crop with insect pollination ( $A E V)$ was calculated as follows: Indicates the crop yield

$$
A E V=P_{i 1} \times Q_{i 1}
$$

$P_{i 1}$ is the crop yield, and $Q_{i 1}$ is the product price. Then, the economic value of crop without insect pollination $(P E V)$ was calculated as follows: Indicates the crop yield

$$
P E V=P_{i 2} \times Q_{i 2}
$$

where $P_{i 2}$ is the crop yield, and $Q_{i 2}$ is the product price. $P_{i}$ values result from the aforementioned insect pollination experiment, and $Q_{i}$ values were obtained in a field survey. Based on the obtained values of $P E V$ and $A E V$, the dependence of crops on insect pollination was calculated as follows:

$$
D_{i}=\frac{(A E V-P E V)}{A E V} \times 100 \%
$$

\subsection{Distribution and Number of Managed Bees}

An experiment was conducted in a circle with a radius of $1000 \mathrm{~m}$ and centered at the rapeseed test field to record the species, number, and distribution of managed bees within and outside the homegarden in 2017 [50,51], including the species, number, and management methods of the bees. Moreover, the species, quantity, and distribution of managed bees within and outside the homegarden in 2008 was evaluated using a questionnaire survey and interviews. 


\subsection{Changes in Insect Habitat Patterns}

The changes in the number and areas of homegardens in 2005 to 2015 were identified according to the relevant reference [47]. A comparative analysis was used to identify the effects of homegarden composition and structural changes on the distribution of wild insect habitats.

\subsection{Data Analysis}

The Arcgis 9.3 software was used to organize and calculate spatial data. The SPSS 19.0 software was used to collate data and perform significance tests. The Sigmaplot 12.0 software was used to prepare graphs.

\section{Results}

\subsection{Pollinator Species and Number of Flower-Visits}

A total of 23 flower-visiting pollinator species, including bees, butterflies, and moths, were recorded at the experimental sites. Of these 23 species, four were managed bees and 19 were wild insects. The 8:00 to 19:00 period was the main activity period for flower-visiting insects, and the visits were especially numerous from 11:00 to 15:00. The numbers of wild insect visits from 8:00 to 10:00 and 17:00 to 19:00 were similar to, or higher than, those of the managed bees, whereas in other periods (10:00 to 17:00), flower-visits by managed bees were significantly higher than those of wild insects. The number of visits to peaches (100 flowers) was approximately 8427 per day, with $76.61 \%$ of visits made by managed bees. The number of visits to plums (100 flowers) was approximately 2447 per day, with $67.55 \%$ of visits made by managed bees. The number of visits to rapeseed (100 inflorescences) was approximately 14,726 per day, with $74.66 \%$ of visits made by managed bees (Figure 4 ).
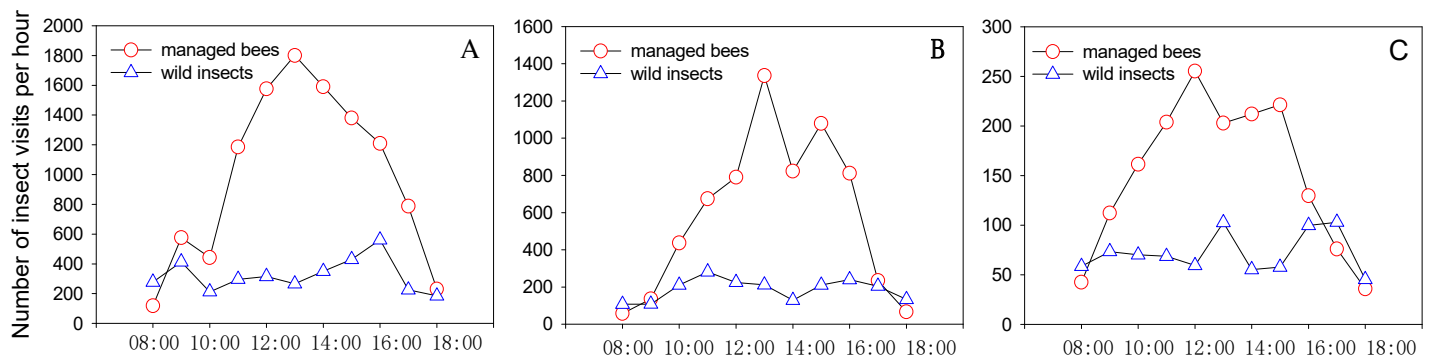

Figure 4. Monitoring of the pollination activity of managed bees and wild insects. (A) Rape; (B) Peach; (C) Plum.

\subsection{Agricultural Crop Yield and Quality}

When compared with the CK treatment, the average seed numbers of rapeseed from treatments A and B were significantly lower $(p<0.05)$, and the yield per unit area was significantly reduced, by $40.46 \%$ to $47.32 \%$ ( $p<0.01$ ), but the 1000 -grain weight was not affected. There were no significant differences in fruit size, yield, or sweetness between treatments A, B, and CK in plums. The size and weight of peach fruit in treatments A and B were significantly $(p<0.05)$ reduced when compared with those of CK. The weight of a single fruit was reduced by $28.54 \%$ to $36.38 \%$ and the fruit sweetness was significantly $(p<0.01)$ decreased (Figure 5). 

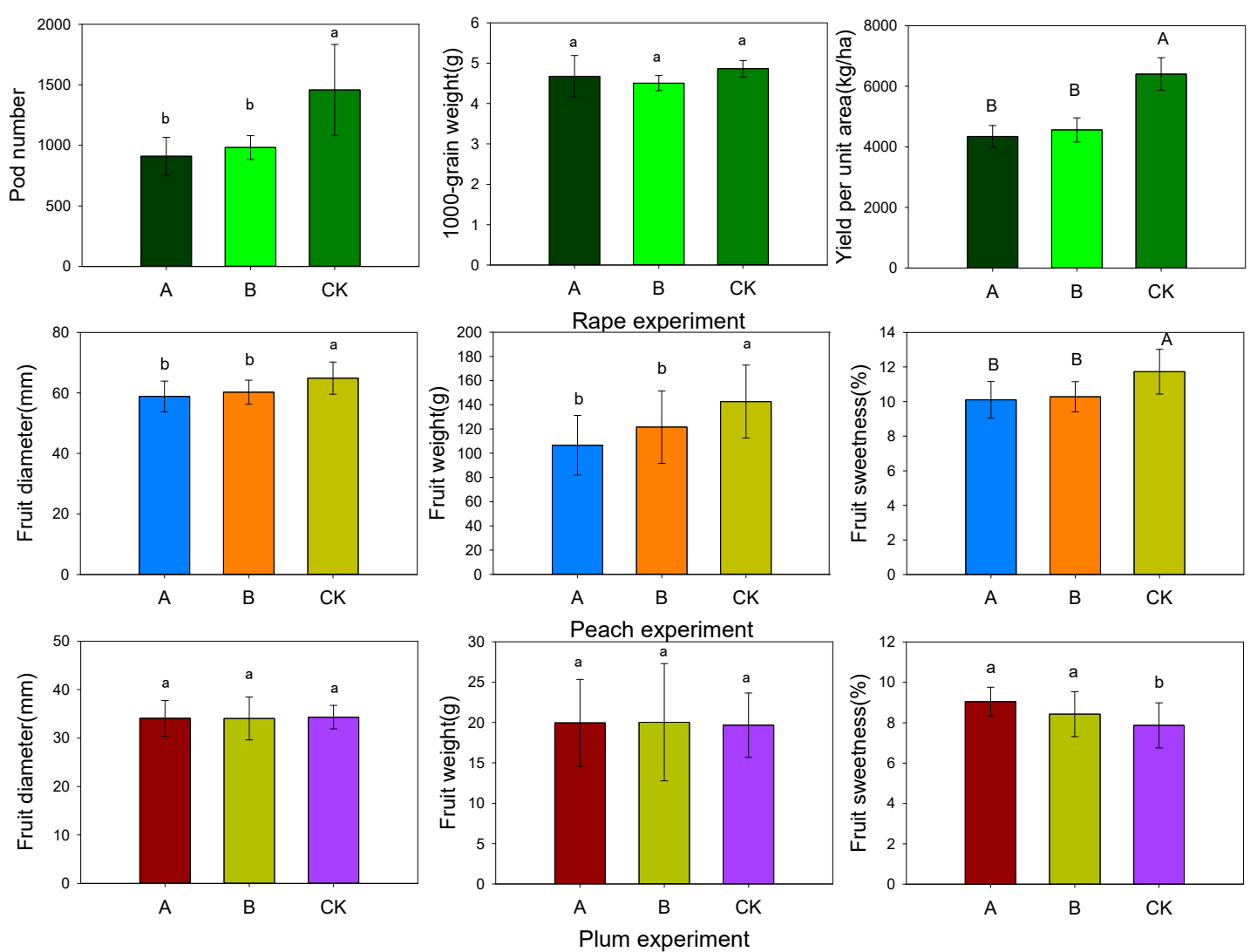

Figure 5. Effect of pollination on crop yield and quality. A, B, CK indicate different treatments.

\subsection{Crop Pollination Dependence $\left(D_{i}\right)$}

The calculation of $D_{i}$ showed that the dependence of rapeseed on insect pollination was 0.56 . In 2018, the rapeseed yield in this area was 203,840 tons, and the contribution of insect pollination was approximately $\$ 85.1$ million. In contrast, the dependence of plum on insect pollination was low. The dependence of peach on insect pollination was 0.44 . The yield of peach in this area was 67,500 tons, and the contribution of insect pollination was approximately $\$ 31.0$ million.

\subsection{Survey of Managed Bees}

Within the $1000 \mathrm{~m}$ circle (Figure 6), there were four species and a total of 186 beehives (the number of bees per hive is approximately 3 to 4 million) of managed bees. Among them, 74 beehives $(39.78 \%)$ were in the homegarden, four beehives (2.16\%) were at the new rural community, and 108 beehives (58.06\%) were from external sources, mainly Yunnan Province and Gansu Province, and bees were present from March to May. In 2008, the number of homegardens in the study area was $17.24 \%$ higher than the number in 2017, 195 beehives of managed bees were in homegardens, there were no external bees outside the homegardens, and $27.94 \%$ of the homegardens had managed bees. Currently, the abundance of the managed bee species is also decreasing. Therefore, the farmland in the Chengdu Plain has a high degree of dependence on managed bees from external sources. The number of local beekeepers is decreasing, especially in the new rural community. 

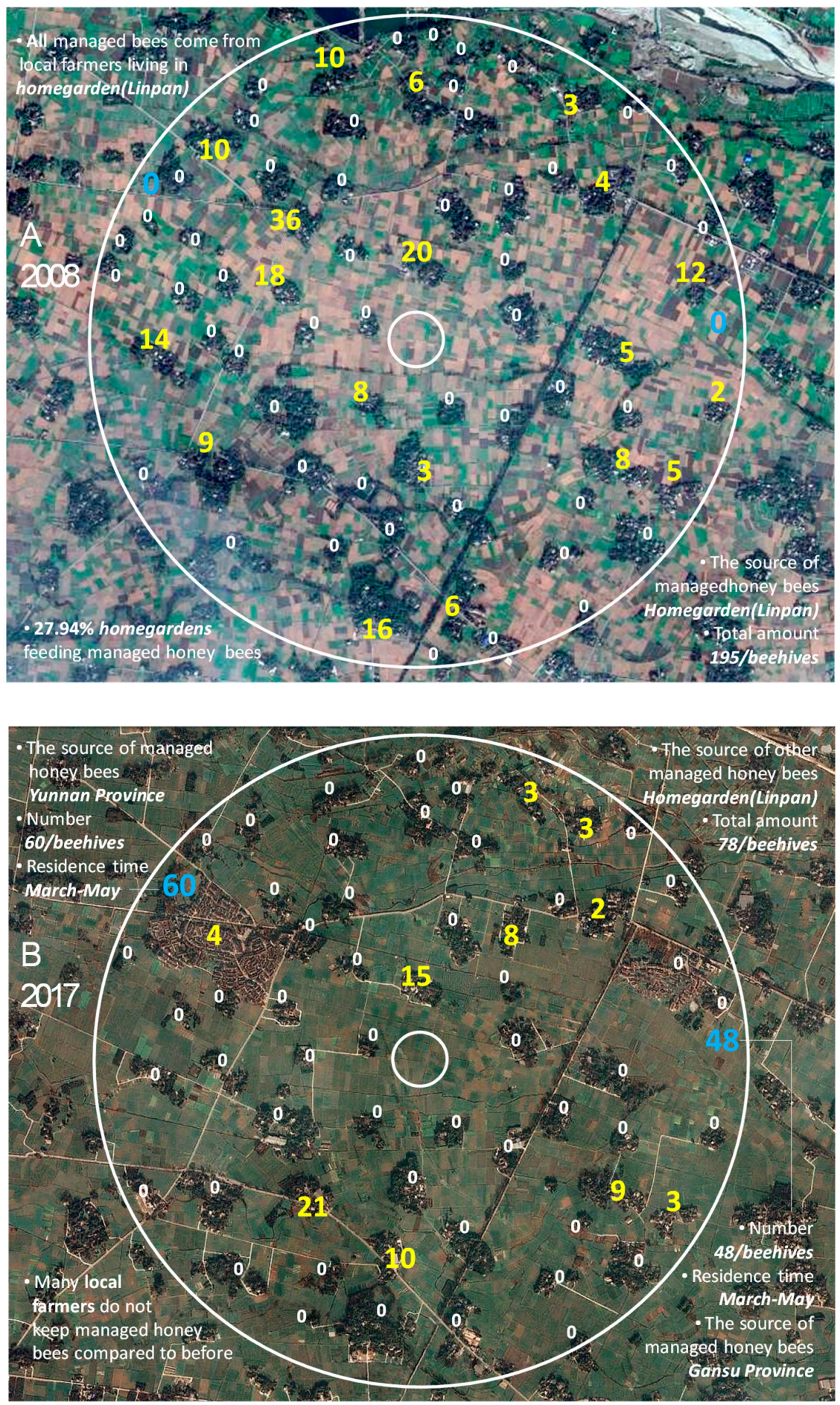

Figure 6. Distribution of managed bees in the study area in 2008 and 2017.

\section{Discussion}

\subsection{Result Accuracy and Error}

The present study identified the importance of insect pollination services in the Chengdu Plain through comparative experiments and field investigations. We have revealed the risk to pollination services caused by the decrease in diversity and population of both managed bees and wild insects. The findings of the impacts of insect pollination services on the yield and quality of rapeseed and 
peach were similar to that previously reported $[49,52,53]$. Moreover, the price difference caused by the decrease of crop quality is reflected in the calculation of $D_{i}$, which makes the results of this study more accurate. The pod rate and fruit setting rate were not included in this study [52,53], but this did not affect the conclusion. Plums have a low pollination dependence (0.3), so the impact here was not significant [54,55]. In fact, the dependence on insect pollination in $60.64 \%$ of all global crop varieties is over 0.5 [4], and therefore the importance of pollination services should not be underestimated. In this study, 23 species of pollinators were identified, a number significantly lower than that for the adjacent mountainous areas [56], indicating that species diversity in the plains area is lower [57]. There is also an error caused by the lack of nighttime survey data. According to the flower-visiting data, bees accounted for more than $67.55 \%$ of the visits, which is not optimal because wild pollinators can provide a wider and more stable pollination service $[1,51,58]$, but it basically reflects the current agricultural situation [49]. Insect visits to flowers were mostly between 11:00 to 15:00, which is related to insect activity rhythm and plant nectar and pollen volume [59], which are based on suitable temperature and humidity [60]. Bees and other insects have different presence times and peak periods, which may be related to a high number of bees being able to exclude other insects from visiting flowers [61]. The number of insect visits to rapeseed, peach, and plum can loosely reflect the differences in pollination of different crops [59], but these numbers cannot be completely compared because the flowering periods of the three crops are slightly different and the insect visiting frequencies are linearly correlated with the flowering coverage area and quantity [62].

\subsection{The Importance and Uniqueness of Insect Pollination Services}

\section{Importance}

The Chengdu Plain is very important for agricultural security [30,31]. It provides agricultural resources for 82.62 million people, and its agricultural output per unit area is 1.08 times that of the average for China. The region is rich in water and soil resources, with suitable climate [31]. Have pollination services become a limiting factor for agricultural development in this area? The answer is yes. According to the list of pollination dependence provided by the FAO (Food and Agriculture Organization) [4,6], 53.91\% of the crops in the Chengdu Plain require insect pollination, and pollination dependence is over 0.5. At the same time, insect-pollinated crops can experience significant increases in micronutrient [63] and seed RNA content [53], thus improving crop quality [64]. The average unit price of insect pollination-dependent crops is 5.04 times that of non-dependent crops $[6,8]$.

\section{Uniqueness}

The homegarden plays an irreplaceable role in insect pollination services in the Chengdu Plain. First, there are no other large-scale forest resources in the plain areas [65]. The vegetation in the homegarden can provide habitat $[4,22,66]$ and food sources for pollinators $[62,67,68]$, and the sun and soil conditions in this semi-natural habitat may be favorable to insect nesting and growth [69-71]. Second, the average density of homegardens in this region is approximately $14.64 \mathrm{~km}^{2}$ [38], which has better dispersion and edge effects than a smaller forest [72] and is favorable for the formation of a pollination network with wide coverage [21,73]. This type of nested and asymmetric symbiotic network has great stability and adaptability $[74,75]$, increasing the efficiency of pollination services (the optimal radius of insect activity is approximately 750 to $1000 \mathrm{~m}$ ) [76,77].

\section{Easily Neglected}

The importance of insect pollination services has not generated enough attention from the local farmers. Most farmers believe that improving soil fertility and irrigation conditions is the only way to increase crop yields and improve quality [8]. More than $40 \%$ of the farmers believe that pollination is not an essential investment in agriculture, and $36.83 \%$ of the farmers believe that pollination can be replaced [57]. In some areas, increased crop yields with decreased pollination services may seem to validate this conclusion [78]. In fact, the increased yields may be the result of improved cultivars, 
fertilizer inputs, or improved farming techniques. Pollination services are irreplaceable in terms of production stability and quality assurance [48,51].

\subsection{The Main Challenges to Insect Pollination in the Chengdu Plain}

\section{Loss of insect habitat}

Overall, $27 \%$ of the traditional Linpan in the Chengdu Plain have disappeared, and $40 \%$ have been destroyed from 2005 to 2015 [46,47] (Figure 7), resulting in a loss of habitat for wild insects [23,79,80] and a decrease in the number of managed bees. New rural communities rarely continue to manage bees [81,82]. The destruction of homegardens leads to a decrease in plant diversity and quantity [34], which is harmful to the stability of pollination services $[25,26]$. A large quantity of impervious ground and brick-concrete houses have replaced soil structures and can also destroy insect nests [83] (Figure 8). Landscape planning in the Chengdu Plain includes instructions that many homegardens will be demolished and consolidated, which will increase the average distance between insect habitat and farmland from 150 to $300 \mathrm{~m}$, thus reducing the benefits of pollination services [84-86]. Even after the restoration of homegarden vegetation, it is difficult to restore insect diversity and population to pre-destruction levels in a short time [87].
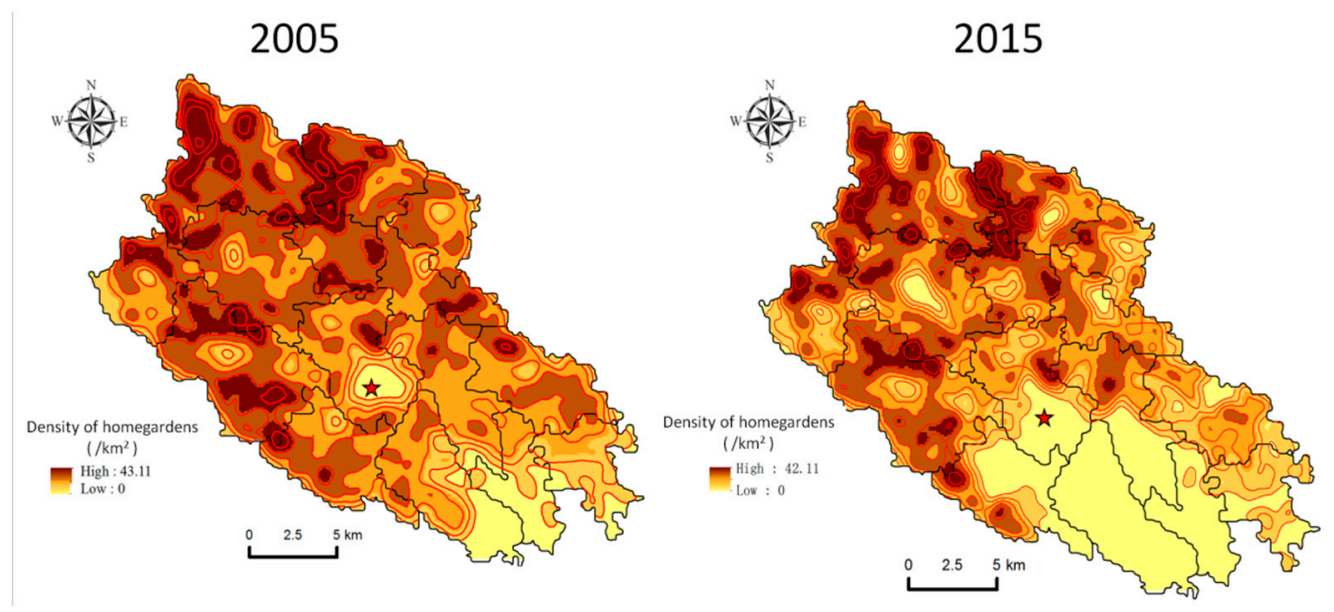

Figure 7. The Kernel density map of homegardens in Pixian in 2005 and 2015.

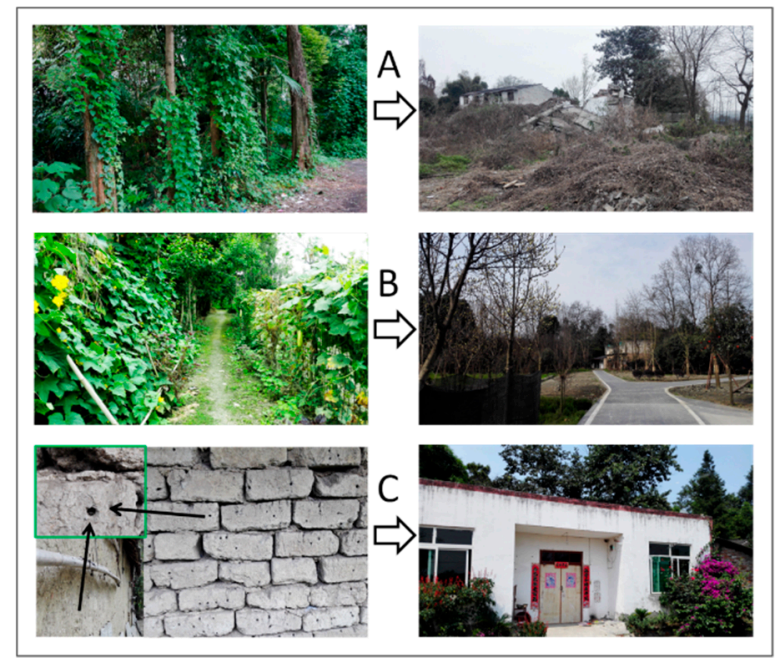

Figure 8. Damage to wild insect habitats. (A) damage to vegetation; (B) impervious surface area increase; (C) building unloading and structural change. 


\section{High dependence on managed bees}

According to the pollinator types and flower-visiting rates, the majority of pollinators in the Chengdu Plain are managed bees, $58.06 \%$ of which are dependent on foreign beekeepers. In terms of short-term benefits, managed bees can ensure an adequate total number of pollinators. However, in terms of sustainability, an increased number of managed bees could lead to ecological risks [50]. Wild insects provide a broader and more stable pollination service [1,51], and many crops rely more on wild insects to maximize their yield and quality [51,58]. Managed bees can disrupt the area and intensity of wild insect activity [88], leading to a reduction in their population [89-91]. Managed bees are more susceptible to diseases, pesticides, and other environmental stressors [12], leading to rapid population declines and transmission of diseases to wild insects [19]. Therefore, maintaining the diversity of pollinators can improve the synergy among species as well as their temporal and spatial complementarity $[86,90,91]$, which is very important in improving the quality and stability of pollination [92].

\section{Agricultural intensification management}

Scaled-up and intensified agricultural management has gradually become a trend. Studies have shown that agricultural intensification can reduce landscape heterogeneity and connectivity [21] and destroy habitats and is harmful to insect pollination [4,10]. At the same time, mechanized farming based on cultivated land intensification management could destroy soil-nesting insects and their eggs $[93,94]$. Large amounts of pesticides and insecticides could damage the insect life cycle and feeding behavior [95-99]. For example, pesticide application per unit area in the Chengdu region is $75.13 \%$ higher than the national average, which has increased $24.17 \%$ when compared with 20 years ago.

\subsection{Insect Pollination Services Improvement Plan}

\section{Strengthen homegarden protection and planning}

First, insect pollination services need to be taken into consideration when implementing a spatial protection plan in homegardens. Attention needs to be paid to the scale of the distance during demolition and consolidation of the homegardens. The size of the new rural community should not be too large, and the homegardens that are partially demolished or planned to be converted into cultivated land should instead be retained as ecological lands. Second, the plan enhances protection of plant diversity and population numbers in the homegarden, increases the numbers of economic forest grass, ornamental plantations, etc., and promotes an improvement in the synergy between insect pollination services and product supply, regulation, and landscape services of the ecosystem [100,101].

\section{Organic farming measures}

The plan also acts to reinforce the ecological management of farmland in the Chengdu Plain. For example, farmers should improve agricultural diversity, avoiding single crop varieties, arrange forest patches [20], flower strips, or hedges around farmland [18,19,102,103], and reduce pesticide inputs [24]. They should also proactively adopt ecological pest control and disease prevention measures [24]. The plan increases farmer awareness of protecting both the diversity of wild insect species and managed bees in order to maintain the stability of the pollinator community $[104,105]$.

\section{Conclusions}

This study shows that insect pollination services are very important for agricultural production in the Chengdu Plain. In particular, the widely distributed rural homegardens known as 'Linpan' are major irreplaceable habitats for insects. However, insect pollination services are at increased risk because of the small number of pollinators, high dependence on managed bees, reduction of locally managed bee populations, destruction of Linpan vegetation, and intensified agricultural management. In view of the high dependence on managed bees and the reduction in wild pollinators in the Chengdu 
Plain, this paper proposes the establishment of a collaborative plan for rural homegarden protection and organic farming in order to improve the efficiency of insect pollination services.

Author Contributions: Q.L. conceptualized the idea and completed the experimental design, conducted experiment monitoring and field surveys, collected and analyzed data; P.X. guided the design of the work and help to finalize the manuscript through regular discussion and critical revisions; K.Y. and Y.G. assisted in the completion of field surveys, data processing and analysis.

Funding: This research was funded by national natural science foundation of China (No. 41401664).

Acknowledgments: This work was supported by the 135 strategic program of the institute of mountain hazards and environment, CAS (No. SDS-135-1703).

Conflicts of Interest: The authors declare no conflict of interest.

\section{References}

1. Hoehn, P.; Tscharntke, T.; Tylianakis, J.M.; Dewenter, I.S. Functional group diversity of bee pollinators increases crop yield. Proc. Boil. Sci. 2008, 275, 2283-2291. [CrossRef] [PubMed]

2. Winfree, R.; Gross, B.J.; Kremen, C. Valuing pollination services to agriculture. Ecol. Econ. 2011, 71, 80-88. [CrossRef]

3. Board, M.E.A. Ecosystems and Human Well-being: Synthesis. Phys. Teach. 2005, 34, 534.

4. Klein, A.M.; Vaissière, B.E.; Cane, J.H.; Steffan-Dewenter, I.; Cunningham, S.A.; Kremen, C.; Tscharntke, T. Importance of Pollinators in Changing Landscapes for World Crops. Proc. Boil. Sci. 2007, 274, 303-313. [CrossRef] [PubMed]

5. Lautenbach, S.; Seppelt, R.; Liebscher, J.; Dormann, C.F. Spatial and Temporal Trends of Global Pollination Benefit. PLoS ONE 2012, 7, e35954. [CrossRef]

6. Gallai, N.; Salles, J.M.; Settele, J.; Vaissière, B.E. Economic valuation of the vulnerability of world agriculture confronted with pollinator decline. Ecol. Econ. 2009, 68, 810-821. [CrossRef]

7. Garratt, M.P.D.; Breeze, T.D.; Jenner, N.; Polce, C.; Biesmeijer, J.C.; Potts, S.G. Avoiding a bad apple: Insect pollination enhances fruit quality and economic value. Agric. Ecosyst. Environ. 2014, 184, 34-40. [CrossRef] [PubMed]

8. Tscharntke, T.; Clough, Y.; Wanger, T.C.; Jackson, L.; Motzke, I.; Perfecto, I.; Vandermeer, J.; Whitbread, A. Global food security, biodiversity conservation and the future of agricultural intensification. Boil. Conserv. 2012, 151, 53-59. [CrossRef]

9. Gonzálezvaro, J.P.; Biesmeijer, J.C.; Bommarco, R.; Potts, S.G.; Schweiger, O.; Smith, H.G.; Steffan-Dewenter, I.; Szentgyrgyi, H.; Woyciechowski, M.; Vilà, M. Combined effects of global change pressures on animal-mediated pollination. Trends Ecol. Evol. 2013, 28, 524-530. [CrossRef]

10. Deguines, N.; Jono, C.; Baude, M.; Henry, M.; Julliard, R.; Fontaine, C. Large-scale trade-off between agricultural intensification and crop pollination services. Front. Ecol. Environ. 2016, 12, 212-217. [CrossRef]

11. Vanbergen, A.J. Threats to an ecosystem service: Pressures on pollinators. Front. Ecol. Environ. 2013, 11, 251-259. [CrossRef]

12. Neumann, P.; Carreck, N.L. Honey bee colony losses. J. Apic. Res. 2010, 49, 1-6. [CrossRef]

13. Albrecht, M.; Duelli, P.; Muller, C.; Kleijn, D.; Schmid, B. The Swiss agri-environment scheme enhances pollinator diversity and plant reproductive success in nearby intensively managed farmland. J. Appl. Ecol. 2007, 44, 813-822. [CrossRef]

14. Klein, A.; Brittain, C.; Hendrix, S.D.; Thorp, R.; Williams, N.; Kremen, C. Wild pollination services to California almond rely on semi-natural habitat. J. Appl. Ecol. 2012, 49, 723-732. [CrossRef]

15. Brosi, B.J.; Armsworth, P.R.; Daily, G.C. Optimal design of agricultural landscapes for pollination services. Conserv. Lett. 2008, 1, 27-36. [CrossRef]

16. Scheper, J.; Holzschuh, A.; Kuussaari, M.; Potts, S.G.; Rundlf, M.; Smith, H.G.; Kleijn, D. Environmental factors driving the effectiveness of European agri-environmental measures in mitigating pollinator loss-A meta-analysis. Ecol. Lett. 2013, 16, 912-920. [CrossRef]

17. Hannon, L.E.; Sisk, T.D. Hedgerows in an agri-natural landscape: Potential habitat value for native bees. Boil. Conserv. 2009, 142, 2140-2154. [CrossRef] 
18. Korpela, E.L.; Hyvönen, T.; Lindgren, S.; Kuussaari, M. Can pollination services, species diversity and conservation be simultaneously promoted by sown wildflower strips on farmland? Agric. Ecosyst. Environ. 2013, 179, 18-24. [CrossRef]

19. Kremen, C.; Miles, A. Ecosystem Services in Biologically Diversified versus Conventional Farming Systems: Benefits, Externalities, and Trade-Offs. Ecol. Soc. 2012, 17, 388-395. [CrossRef]

20. Roschewitz, I.; Gabriel, D.; Tscharntke, T.; Thies, C. The effects of landscape complexity on arable weed species diversity in organic and conventional farming. J. Appl. Ecol. 2005, 42, 873-882. [CrossRef]

21. Rossum, F.V. Reproductive success and pollen dispersal in urban populations of an insect-pollinated hay-meadow herb. Perspect. Plant Ecol. Evol. Syst. 2010, 12, 21-29. [CrossRef]

22. Marshall, E.; Moonen, A.C. Field margins in northern Europe: Their functions and interactions with agriculture. Agric. Ecosyst. Environ. 2002, 89, 5-21. [CrossRef]

23. Potts, S.G.; Biesmeijer, J.C.; Kremen, C.; Neumann, P.; Schweiger, O.; Kunin, W.E. Global pollinator declines: Trends, impacts and drivers. Trends Ecol. Evol. 2010, 25, 345-353. [CrossRef]

24. Kennedy, C.M.; Lonsdorf, E.; Neel, M.C.; Williams, N.M.; Ricketts, T.H.; Winfree, R.; Bommarco, R.; Brittain, C.; Burley, A.L.; Cariveau, D.; et al. A global quantitative synthesis of local and landscape effects on wild bee pollinators in agroecosystems. Ecol. Lett. 2013, 16, 584-599. [CrossRef]

25. Winfree, R.; Kremen, C. Are ecosystem services stabilized by differences among species? A test using crop pollination. Proc. Boil. Sci. 2009, 276, 229-237. [CrossRef]

26. Ricou, C.; Schneller, C.; Amiaud, B.; Plantureux, S.; Bockstaller, C. A vegetation-based indicator to assess the pollination value of field margin flora. Ecol. Indic. 2014, 45, 320-331. [CrossRef]

27. Freitas, B.M.; Imperatrizfonseca, V.L.; Medina, L.M.; Kleinert, A.M.P.; Galetto, L.; Parra, G.N.; Quezada-Euán, J.J.G. Diversity, threats and conservation of native bees in the Neotropics. Apidologie 2009, 40, 332-346. [CrossRef]

28. Lowenstein, D.M.; Matteson, K.C.; Minor, E.S. Diversity of wild bees supports pollination services in an urbanized landscape. Oecologia 2015, 179, 811-821. [CrossRef]

29. Li, H.Y. Economic Value of Bee Pollination in China. Ph.D. Thesis, Fujian Agriculture and Forestry University, Fuzhou, China, 2012.

30. Guedes, J.D.A. Millets, Rice, Social Complexity, and the Spread of Agriculture to the Chengdu Plain and Southwest China. Rice 2011, 4, 104-113. [CrossRef]

31. Fang, Z.R.; Li, X.K. On Causes for Formation of Linpan culture in West Sichuan Plain. J. Chengdu Univ. 2011, $5,45-49$.

32. Li, Y.F.; Zhan, J.Y.; Liu, Y.; Zhang, F.; Zhang, M.L. Response of ecosystem services to land use and cover change: A case study in Chengdu City. Resour. Conserv. Recycl. 2017, 132, 291-300. [CrossRef]

33. Yang, Q.J.; Li, B.; Li, K. The Rural Landscape Research in Chengdu's Urban-rural Intergration Development. Procedia Eng. 2011, 21, 780-788.

34. Liu, Q.; Wang, Y.K.; Guo, Y.M.; Peng, P.H.; Wang, K.Y. Morphological characteristics and composition of plant species and their distribution patterns in Linpan of Chengdu plain. Acta Ecol. Sin. 2018, 38, 3553-3561.

35. Nair, P.K.R. Do tropical homegardens elude science, or is it the other way around? Agrofor. Syst. 2001, 53, 239-245. [CrossRef]

36. Trinh, L.N.; Watson, J.W.; Hue, N.N.; De, N.N.; Minh, N.V.; Chu, P.; Sthapit, B.R.; Eyzaguirre, P.B. Agrobiodiversity conservation and development in Vietnamese home gardens. Agric. Ecosyst. Environment. 2003, 97, 317-344. [CrossRef]

37. Kabir, M.E.; Webb, E.L. Household and homegarden characteristics in southwestern Bangladesh. Agrofor. Syst. 2009, 75, 129-145. [CrossRef]

38. Guo, Y.M.; Xu, P.; Liu, Q.; Wang, K.Y.; Wang, H.W. Spatial Distribution Characteristics of Linpan in Chengdu Plain-A Case of Pi County. J. Southwest China Norm. Univ. (Nat. Sci. Ed.) 2017, 42, 121-126.

39. Luo, Z.; Yang, C.J.; Li, X.W. Extracting the Rural Residential Information from High Resolution Satellite Imagery. Geospat. Inf. 2009, 7, 80-82.

40. Shu, B. Research on the Agriculture Landscape of Cheng Plain. Ph.D. Thesis, Southwest Jiaotong University, Chengdu, China, 2011.

41. Koohafkan, P.; Altieri, M.A. Globally Important Agricultural Heritage Systems (GIAHS). A Legacy for the Future; Food and Agriculture Organization of the United Nations: Rome, Italy, 2011.

42. Nath, A.J.; Das, A.K. Carbon storage and sequestration in bamboo-based smallholder homegardens of Barak Valley, Assam. Curr. Sci. 2011, 100, 229-233. 
43. Galhena, D.H.; Freed, R.; Maredia, K.M. Home gardens: A promising approach to enhance household food security and wellbeing. Agric. Food Secur. 2013, 2, 1-13. [CrossRef]

44. Mohri, H.; Lahoti, S.; Saito, O.; Mahalingam, A.; Gunatilleke, N.; Hitinayake, G.; Takeuchi, K.; Herath, S. Assessment of ecosystem services in homegarden systems in Indonesia, Sri Lanka, and Vietnam. Ecosyst. Serv. 2013, 5, 124-136. [CrossRef]

45. Karthigesu, J.; Sivachndiran, S.; Pushpakumara, D.; Weerahewa, J. Ecosystem Services of Homegarden Agroforestry in Jaffna Peninsula. Int. Conf. Dry Zone Agric. 2016, 3, 56-68.

46. Zhou, Y.; Chen, J. Landscape Pattern Change and Its Driving Forces in the Linpan of Western Sichuan. J. Sichuan Agric. Univ. 2017, 35, 241-250.

47. Guo, Y.M. Study on Spatial-TemporalVariation Characteristics and Driving Forces of Linpan in Chengdu Plain-A Case of Pi County. Master. Thesis, University of Chinese Academy of Science, Beijing, China, 2017.

48. Klatt, B.K.; Holzschuh, A.; Westphal, C.; Clough, Y.; Smit, I.; Pawelzik, E.; Tscharntke, T. Bee pollination improves crop quality, shelf life and commercial value. Proc. R. Soc. B Boil. Sci. 2014, 281, 20132440. [CrossRef]

49. Luo, W.H.; Dai, R.G.; Wang, R.S.; Cao, L.; Guo, J.; Ren, Q.; Ji, C.H.; Cheng, S. Study on the effect of insect pollination on rapeseed in Chongqing area. Heilongjiang Anim. Sci. 2014, 11, 120-121.

50. Holzschuh, A.; Dudenhöffer, J.H.; Tscharntke, T. Landscapes with wild bee habitats enhance pollination, fruit set and yield of sweet cherry. Boil. Conserv. 2012, 153, 101-107. [CrossRef]

51. Garibaldi, L.A.; Steffan-Dewenter, I.; Kremen, C.; Morales, J.M.; Bommarco, R.; Cunningham, S.A.; Carvalheiro, L.G.; Chacoff, N.P.; Dudenhffer, J.H.; Greenleaf, S.S.; et al. Stability of pollination services decreases with isolation from natural areas despite honey bee visits. Ecol. Lett. 2011, 14, 1062-1072. [CrossRef]

52. He, J.H.; Li, Y.L.; Yang, Y.J.; Zhao, J.; Wu, T.; Wu, Z.X.; Zhao, G.; Dong, K.; He, S.Y. Study on The Effects of Pollination by Honey-Bees on Peach Tress. J. Bee 2011, 30, 5-6.

53. Shi, Y.Y.; Guan, C.; Zeng, Z.J.; An, J.D.; Luo, S.D. Yield-Increasing Effect and Mechanism of Honey bee on Rape Pollination. Acta Agric. Univ. Jiangxiensis 2009, 31, 994-999.

54. Liu, P.F.; Wu, J.; Li, H.Y.; Lin, S.W. Economic Values of Bee Pollination to China's Agriculture. Sci. Agric. Sin. 2011, 44, 5117-5123.

55. An, D.J.; Chen, W.F. Economic value of insect pollination for fruits and vegetables in China. Acta Èntomol. Sin. 2011, 54, 443-450.

56. Zhong, Y.H.; Zhao, D.X.; Gao, J.L.; Wang, Y.J.; Liu, J.F. Study of Pollinating Insect of Dimocarpus longana. Apic. China. 2014, 65, 61-63.

57. Li, Y.H.; Xiang, B.; Yuan, X.Z.; Xie, Q.; Li, L.; Ma, G.W. Characteristics of biodiversity spatial differentiation in the Chengdu-Chongqing economic zone. Res. Environ. Sci. 2012, 25, 1148-1154.

58. Garibaldi, L.A.; Steffan-Dewenter, I.; Winfree, R.; Aizen, M.A.; Bommarco, R.; Cunningham, S.A.; Kremen, C.; Carvalheiro, L.G.; Harder, L.D.; Afik, O.; et al. Wild pollinators enhance fruit set of crops regardless of honey bee abundance. Science 2013, 339, 1608-1611. [CrossRef] [PubMed]

59. Li, Z.; Yang, G.D.; Duan, Y.F.; Fan, Y.; Zhao, Y.P.; Cheng, J.R.; Wang, X.R. Study on major pollinators and their flower-visiting behavior of Osmanthus fragrans. J. Nanjing For. Univ. (Nat. Sci. Ed.) 2014, s1, 47-50.

60. Luo, C.W.; Li, K.; Chen, X.M.; Chen, Y.; Sun, Y.Y. Foraging and main pollinators of Jatropha curcas in dry-hot valley. Chin. Bull. Entomol. 2008, 45, 121-127.

61. Shen, J.S.; Qi, H.P.; Guo, Y.; Shao, Y.Q.; Liu, Y.M. Investigation on Sunflower Pollinating Insects. Apic. China 2008, 59, 27-28.

62. Ebeling, A.; Klein, A.M.; Schumacher, J.; Weisser, W.W.; Tscharntke, T. How does plant richness affect pollinator richness and temporal stability of flower visits? Oikos 2010, 117, 1808-1815. [CrossRef]

63. Elisabeth, J.E.; Sarah, C.K.; Greenleaf, S.; Garber, A.K.; Klein, A.M. Contribution of pollinator-mediated crops to nutrients in the human food supply. PLoS ONE 2011, 6, e21363.

64. Hudewenz, A.; Pufal, G.; Bogeholz, A.L.; Klein, A.M. Cross-pollination benefits differ among oilseed rape varieties. J. Agric. Sci. 2014, 152, 770-778. [CrossRef]

65. Huang, C.D.; Zhang, J.; Yang, W.J.; Tang, X. Spatiotemporal variation of carbon storage in forest vegetation in Sichuan Province. Chin. J. Appl. Ecol. 2007, 18, 2687-2692.

66. Blaauw, B.R.; Isaacs, R. Flower plantings increase wild bee abundance and the pollination services provided to a pollination-dependent crop. J. Appl. Ecol. 2014, 51, 890-898. [CrossRef]

67. Mandelik, Y.; Winfree, R.; Neeson, T.; Kremen, C. Complementary habitat use by wild bees in agro-natural landscapes. Ecol. Appl. 2012, 22, 1535. [CrossRef] 
68. Heard, M.S.; Carvell, C.; Carreck, N.L.; Rothery, P.; Osborne, J.L.; Bourke, A.F.G. Landscape context not patch size determines bumble-bee density on flower mixtures sown for agri-environment schemes. Boil. Lett. 2007, 3, 638-641. [CrossRef]

69. Williams, N.M.; Kremen, C. Resource distributions among habitats determine solitary bee offspring production in a mosaic landscape. Ecol. Appl. 2007, 17, 910-921. [CrossRef]

70. Klein, A.M.; Steffan-Dewenter, I.; Tscharntke, T. Fruit set of highland coffee increases with the diversity of pollinating bees. Proc. Biol. Sci. 2003, 270, 955-961. [CrossRef]

71. Winfree, R.; Griswold, T.; Kremen, C. Effect of human disturbance on bee communities in a forested ecosystem. Conserv. Biol. 2007, 21, 213-223. [CrossRef]

72. Jha, S.; Vandermeer, J.H. Impacts of coffee agroforestry management on tropical bee communities. Boil. Conserv. 2010, 143, 1423-1431. [CrossRef]

73. Holzschuh, A.; Steffandewenter, I.; Tscharntke, T. How do landscape composition and configuration, organic farming and fallow strips affect the diversity of bees, wasps and their parasitoids? J. Anim. Ecol. 2010, 79, 491-500. [CrossRef]

74. Ramosjiliberto, R.; Albornoz, A.A.; Valdovinos, F.S.; Ramírez, C.S.; Arim, M.; Armesto, J.J.; Marquet, K.A. A network analysis of plant-pollinator interactions in temperate rain forests of Chiloe Island, Chile. Oecologia 2009, 160, 697-706. [CrossRef]

75. Ferreira, P.A.; Boscolo, D.; Viana, B.F. What do we know about the effects of landscape changes on plant-pollinator interaction networks? Ecol. Indic. 2013, 31, 35-40. [CrossRef]

76. Taki, H.; Kevan, P.G.; Ascher, J.S. Landscape effects of forest loss in a pollination system. Landsc. Ecol. 2007, 22, 1575-1587. [CrossRef]

77. Priess, J.A.; Mimler, M.; Klein, A.M.; Schwarntke, T.; Dewenter, I.S. Linking deforestation scenarios to pollination services and ecoonomic returns in coffee agroforestry systems. Ecol. Appl. 2007, 17, 407-417. [CrossRef]

78. Breeze, T.D.; Bailey, A.P.; Balcombe, K.G.; Potts, S.G. Pollination services in the UK: How important are honeybees? Agric. Ecosyst. Environ. 2011, 142, 137-143. [CrossRef]

79. Williams, N.M.; Crone, E.E.; Roulston, T.H.; Minckley, R.L.; Packer, L.; Potts, S.G. Ecological and life-history traits predict bee species responses to environmental disturbances. Boil. Conserv. 2010, 143, 2280-2291. [CrossRef]

80. Olschewski, R.; Tscharntke, T.; Benitez, P.C.; Schwarze, S.; Klein, A.M. Economic Evaluation of Pollination Services Comparing Coffee Landscapes in Ecuador and Indonesia. Ecol. Soc. 2006, 11, 709-723. [CrossRef]

81. Cane, J.H.; Minckley, R.L.; Kervin, L.J.; Roulston, T.H.; Williams, N.M. Complex responses within a desert bee guild (Hymenoptera: Apiformes) to urban habitat fragmentation. Ecol. Appl. 2006, 16, 632-644. [CrossRef]

82. Leong, M.; Kremen, C.; Roderick, G.K. Pollinator interactions with yellow starthistle (Centaurea solstitialis) across urban, agricultural, and natural landscapes. PLoS ONE 2013, 9, e86357. [CrossRef]

83. Benjamin, F.E.; Reilly, J.R.; Winfree, R. Pollinator body size mediates the scale at which land use drives crop pollination services. J. Appl. Ecol. 2014, 51, 440-449. [CrossRef]

84. Erik, Ö.; Henrikg, S. Semi-natural grasslands as population sources for pollinating insects in agricultural landscapes. J. Appl. Ecol. 2007, 44, 50-59.

85. Carvalheiro, L.G.; Seymour, C.L.; Veldtman, R.; Nicolson, S.W. Pollination services decline with distance from natural habitat even in biodiversity-rich areas. J. Appl. Ecol. 2010, 47, 810-820. [CrossRef]

86. Blüthgen, N.; Klein, A.M. Functional complementarity and specialisation: The role of biodiversity in plant-pollinator interactions. Basic Appl. Ecol. 2011, 12, 282-291. [CrossRef]

87. Williams, N.M.; Minckley, R.L.; Silverira, F.A. Variation in native bee faunas and its implications for detecting community changes. Ecol. Soc. 2001, 5, 803-805. [CrossRef]

88. Kenta, T.; Inari, N.; Nagamitsu, T.; Goka, K.; Hiura, T. Commercialized European bumblebee can cause pollination disturbance: An experiment on seven native plant species in Japan. Boil. Conserv. 2007, 134, 298-309. [CrossRef]

89. Greenleaf, S.S.; Williams, N.M.; Winfree, R.; Kremen, C. Bee Foraging Ranges and Their Relationship to Body Size. Oecologia 2007, 153, 589-596. [CrossRef]

90. Brittain, C.; Williams, N.; Kremen, C.; Klein, A.M. Synergistic effects of non-Apis bees and honey bees for pollination services. Proc. Biol. Sci. 2013, 280, 20122767. [CrossRef]

91. Albrecht, M.; Müller, C.B. Diverse pollinator communities enhance plant reproductive success. Proc. Biol. Sci. 2012, 279, 4845-4852. [CrossRef] 
92. Kremen, C.; Williams, N.M.; Bugg, R.L.; Fay, J.P.; Thorp, R.W. The area requirements of an ecosystem service: Crop pollination by native bee communities in California. Ecol. Lett. 2004, 7, 1109-1119. [CrossRef]

93. Roulston, T.A.H.; Goodell, K. The Role of Resources and Risks in Regulating Wild Bee Populations. Annu. Rev. Entomol. 2011, 56, 293. [CrossRef]

94. Lowenstein, D.M.; Matteson, K.C.; Xiao, L.; Silva, A.M.; Minor, E.S. Humans, bees, and pollination services in the city: The case of Chicago, IL (USA). Biodivers. Conserv. 2014, 23, 2857-2874. [CrossRef]

95. Cresswell, J.E. A meta-analysis of experiments testing the effects of a neonicotinoid insecticide (imidacloprid) on honey bees. Ecotoxicology 2011, 20, 149-157. [CrossRef]

96. Brittain, C.; Potts, S.G. The potential impacts of insecticides on the life-history traits of bees and the consequences for pollination. Basic Appl. Ecol. 2011, 12, 321-331. [CrossRef]

97. Di, P.G.; Cavaliere, V.; Annoscia, D.; Varricchio, P.; Caprio, E.; Nazzi, F.; Gargiulo, G.; Pennacchio, F. Neonicotinoid clothianidin adversely affects insect immunity and promotes replication of a viral pathogen in honey bees. Proc. Natl. Acad. Sci. USA 2013, 110, 18466-18471.

98. Goulson, D. REVIEW: An overview of the environmental risks posed by neonicotinoid insecticides. J. Appl. Ecol. 2013, 50, 977-987. [CrossRef]

99. Pettis, J.S.; Vanengelsdorp, D.; Johnson, J.; Dively, G. Pesticide exposure in honey bees results in increased levels of the gut pathogen Nosema. Die Naturwiss. 2012, 99, 153-158. [CrossRef]

100. Wratten, S.D.; Gillespie, M.; Decourtye, A.; Mader, E.; Desneux, N. Pollinator habitat enhancement: Benefits to other ecosystem services. Agric. Ecosyst. Environ. 2012, 159, 112-122. [CrossRef]

101. Melathopoulos, A.P.; Cutler, G.C.; Tyedmers, P. Where is the value in valuing pollination ecosystem services to agriculture? Ecol. Econ. 2015, 109, 59-70. [CrossRef]

102. Brosi, B.J.; Daily, G.C.; Shih, T.M.; Oviedo, F.; Duran, G. The effects of forest fragmentation on bee communities in tropical countryside. J. Appl. Ecol. 2008, 45, 773-783. [CrossRef]

103. Kohler, F.; Verhulst, J.; van Klink, R.; Kleijn, D. At What Spatial Scale Do High-Quality Habitats Enhance the Diversity of Forbs and Pollinators in Intensively Farmed Landscapes? J. Appl. Ecol. 2008, 45, 753-762. [CrossRef]

104. Garibaldi, L.A.; Carvalheiro, L.G.; Leonhardt, S.D.; Aizen, M.A.; Blaauw, B.R.; Isaacs, R.; Kuhlmann, M.; Kleijn, D.; Klein, A.M.; Kremen, C.; et al. From research to action: Enhancing crop yield through wild pollinators. Front. Ecol. Environ. 2016, 12, 439-447. [CrossRef]

105. Antonia, Z.; Lisa, L.; Jeannine, K.; Andreas, M.; Silke, H.; Silvia, D. Maximum foraging ranges in solitary bees: Only few individuals have the capability to cover long foraging distances. Boil. Conserv. 2010, 143, 669-676. 